Meta

Journal des traducteurs

Translators' Journal

\title{
Steps Towards a Translation-Oriented Typology of Technical
} Texts

\section{Reiner Arntz}

Volume 33, numéro 4, décembre 1988

Symposium AILA 1987, Sydney

URI : https://id.erudit.org/iderudit/001905ar

DOI : https://doi.org/10.7202/001905ar

Aller au sommaire du numéro

Éditeur(s)

Les Presses de l'Université de Montréal

ISSN

0026-0452 (imprimé)

1492-1421 (numérique)

Découvrir la revue

Citer cet article

Arntz, R. (1988). Steps Towards a Translation-Oriented Typology of Technical Texts. Meta, 33(4), 468-471. https://doi.org/10.7202/001905ar d'utilisation que vous pouvez consulter en ligne.

https://apropos.erudit.org/fr/usagers/politique-dutilisation/ 


\section{STEPS TOWARDS A TRANSLATION- ORIENTED TYPOLOGY OF TECHNICAL TEXTS}

REINER ARNTZ

Hochschule of Hildesheim, Federal Republic of Germany

In this short paper, I would first of all like to present some approaches towards the compilation of a translation-oriented typology of technical texts ; following this, I shall deal briefly with 3 areas which are of importance for translators and where such a typology of texts can be useful.

Ever since text-linguistics has existed as a branch of linguistics, its proponents have been endeavouring to classify or to typologize (according to different criteria) what is at first glance a very heterogeneous volume of texts ; in this way, a specific linguistics of text types has come into being and over the last two decades this has led to the development of a number of practicable models. Among these, the inductively conceived models were predominant; that is, by applying certain criteria, an attempt was made to develop abstract text types to which actual texts occurring in reality could then be assigned. For example, in the German-speaking area the text typology developed by E. Werlich ${ }^{1}$ has become well-known. This starts by classifying texts as, for example, descriptive, narrative, argumentative or instructive, with the aim of assigning actual texts to these basic types. Another, equally well-known model - that of B. Sandig ${ }^{2}-$ attempts to produce a text typology based on pairs of characteristics (spoken/written, spontaneous/non-spontaneous, monologue form/dialogue form). Basically, these two models, and a number of other approaches developed by text-linguistics, make one universal claim - that they can be applied to texts of all kinds and therefore also to technical texts. At the same time, such typologies refer in principle to one individual language, and are therefore not necessarily translation-oriented.

Of course, translation science, too, has been active, and work has been going on since the beginning of the seventies to develop a translation-oriented text typology in the course of which one has understandably made as much use as possible of the results of research in text-linguistics. Here too I would like briefly to mention two models which were also developed in the German-speaking area and which are both also inductively conceived. The first is a typology developed by $W . W i l s s^{3}$ and his colleagues at the University of Saarbruicken ; here, all conceivable texts are first of all classified according to their function, namely whether their function is to describe, to evaluate, to regulate actions or to motivate actions. These major blocks of text types are then sub-divided further. More well-known in the German-speaking area is the approach made by $K$. Reiss ${ }^{4}$ which is based on the different functions of the language of the text, and thus classifies the texts according to whether the emphasis is on the contents (contentcentred), the form (form-centred) or on an appeal to the reader (appeal-centred).

The aim of such translation-oriented models is to develop criteria on the basis of which a text which occurs in reality can be assigned to a certain text type and at the same time to recommend specific translation strategies for the type of texts and the language pair in question. These kinds of models, too, can strictly speaking be applied uni- 
versally, that is, they deal with every type of text, including technical texts. However, this universal claim does mean that a great deal of generalisation has to be made. Thus, for example, in $K$. Reiss' typology, "technical texts of all types" are assigned to the category of content-centred texts, alongside numerous other types of texts; translation maxims are then developed for these broad, heterogeneous categories.

The fact that such a concept as "technical texts of all types" offers only a very vague basis for a classification of texts becomes obvious when one examines the results of LSP research, which, ever since the sixties, has been developing practically parallel to text linguistics. First of all, research was centred around technical vocabulary as an important element of technical language, before going on to deal with increasingly larger units such as syntagm, sentence and text. However, even at a relatively early stage, it was necessary to consider questions of text typology, at least implicitly, although an actual cooperation with text-linguistics research did not take place at this point. In the early seventies, efforts were made by several researchers to break down the complex phenomenon "technical language" and to give it an inherent structure. Among the different models to be developed, that of L. Hoffmann ${ }^{5}$ is of particular interest for the German language. In Hoffmann's model, technical language has a horizontal and a vertical structure. The horizontal structure involves a classification according to the individual subjects, to which one technical language is assigned in each case. Each of these technical languages is then sub-divided vertically according to a number of criteria. Such criteria are, for example, the degree of abstraction or the communicative situation. In this way, Hoffmann achieves a sub-classification of each individual technical language in several stages.

Using such models as this, LSP research has carried out numerous theoretical and empirical studies over the last 10-15 years. In the course of these, more and more emphasis has been placed on text-oriented problems. It became clear that many of the questions which arose had long since been answered by text-linguistics working on the common language, and that their solutions could be adopted or modified, where necessary. Such an integration of text-linguistic aspects was also supported by the fact that LSP research had long since ceased making a sharp distinction between technical and non-technical language, simply because they overlap so often. As a result, the opportunities for fruitful cooperation between researchers working primarily on the common language and those involved primarily in language for special purposes have increased considerably ; such a cooperation might also result in the compilation of a comprehensive translation-oriented text typology which completely integrates technical text types in their entire complexity. This was also one of the aims of the AILA symposium "Text linguistics and languages for special purposes ${ }^{16}$ which was held in Hildesheim in April 1987.

The first developments in the compilation of a text typology - at least as far as languages for special purposes are concerned - came from areas which were not primarily interested in translating. Today, however, the decisive new ideas come from the field of translating itself, so that today one can in fact speak of a translation-oriented typology of technical texts. This is above all a result of the fact that in recent years the translating of technical texts has gained increasing significance in terms of quantity alone.

Among all the activities which involve translation there are, $I$ believe, three areas in particular which can profit from a translation-oriented typology of texts. These are : the training of translators, terminology science and machine translation. To conclude my paper, I would like to deal briefly with each of these in turn. 
1. In the training of translators ${ }^{7}$, the part played by technical language has, generally speaking, increased considerably. As a result, one of the problems which arise is that of the choice of suitable text material. First of all, the aim must be to choose as wide a range of text types with practical relevance as possible; at the same time, however, one should try to ensure that the level of difficulty, from a technical and, if possible, from a linguistic point of view, gradually increases.

This leads inevitably to questions of text typology. From a translator's point of view it is especially relevant that, particularly in technical texts, the text structures of the source language (L1) are often quite different from those of the target language (L2), and this is a crucial aspect in the compilation of a translation-oriented text typology. In order to solve the various problems that arise in this context, more varied studies of language pairs need to be carried out ; some steps have been made towards the development of a so-called "contrastive textology", which in its methodology is clearly modelled on contrastive linguistics, but much more intensive work needs to be carried out in this field.

2. The second area is terminology science ${ }^{8}$. This too has greatly increased in significance in recent years, above all as a result of the development of major terminological data banks. However, terminological projects can only succeed if the source material on which the terminological study is based is comparable in both languages, both from a linguistic and a technical point of view. It is clearly obvious - at least in theory - that a terminological study cannot produce worthwhile results if, for example, in language $A$ it is based on texts in which one expert or specialist is addressing another, whereas in language $B$ it deals with texts in which an expert is writing to inform an interested layman. The choice of the speech level and thus that of the lexical means is, of course, decisively determined by the person or group of persons being addressed. However, in practice, the rule that only really similar texts or text types can be compared is broken all too often, not least because there are no useful criteria for such a comparison. Therefore, we see the significance of questions of text typology and text linguistics for the field of terminology science, too.

3. Directly connected with the field of terminology and terminology data banks is that of machine translation ${ }^{9}$, which has recently experienced a revival of interest after years of stagnation. Even though there are various views on the prospects of achieving high-quality machine translation in the near future, there is, however, unanimous agreement on the fact that research in this field has brought to light a great deal of useful knowledge for linguistics in general and for translation science in particular.

One frequently hears the somewhat terse statement that machine translation can produce good results if the texts are highly standardized ; this is no doubt correct in principle, but it must of course be verified for each of the systems which have been developed and for every individual subject and for every type of text. Therefore, quite clearly, we are concerned once again with questions of text typology. In order to solve at least some of the many varied problems which arise here, the Institute of Applied Linguistics at the University of Hildesheim is now working on a project, in collaboration with Siemens, to evaluate the Siemens machine translation system METAL. Among other things, the aim is to determine which types of texts can already be machinetranslated and how much work is required for pre-editing and post-editing. Furthermore, we aim to find out how the system can be expanded to deal with additional types of texts. In order to achieve this, it is vital that reliable criteria for the description of text types are established.

I hope that I have been able to show at least some of the many aspects involved at present in the compilation of a typology of technical texts and that furthermore I have 
been able to illustrate what translation science has to offer in the future by carrying out research into text typology.

\section{REFERENCES}

1. E. Werlich (1975) : Typologie der Texte, Heidelberg.

2. B. Sandig (1972) : "Zur Differenzierung gebrauchssprachlicher Textsorten im Deutschen", in : E. Gülich, W. Raible (eds.) : Textsorten : Differenzierungskriterien aus linguistischer Sicht, Frankfurt, pp. 113-124. 3. P. Matt, G. Thiel, G. Thome, W. Wilss (1978) : "Úbersetzungsrelevante Typologie deutscher und französischer Texte", in : Zeitschrift für germanistische Linguistik (ZGL), pp. 223-233.

4. K. Reiss (1982) : Möglichkeiten und Grenzen der Übersetzungskritik, München.

5. L. Hoffmann (1984) : Kommunikationsmittel Fachsprache, $2^{\text {nd }}$ ed., Berlin.

6. R. Arntz (ed.) (1988) : "Textlinguistik und Fachsprache - Text Linguistics and Language for Special Purposes - Linguistique du texte et langue de spécialité", Akten des internationalen übersetzungswissenschaftlichen Symposions der Association internationale de linguistique appliquée (AILA), Hildesheim, 13-16 April 1987, Hildesheim.

7. W. Wilss, G. Thome (ed.) (1984) : "Die Theorie des Übersetzens und ihr Aufschlusswert für die Übersetzungs - und Dolmetschdidaktik - Translation Theory and Its Implementation in the Teaching of Translating and Interpreting", Akten des Internationalen Kolloquiums der Association internationale de linguistique appliquée (AILA), Saarbrücken, 25-30 July 1983, Tübingen.

B. H. Picht, J. Draskau (1985) : Terminology : An Introduction, Guildford (Surrey).

9. A. Blatt, K.-H. Freigang, K.-D. Schmitz, G. Thome (1985) : Computer und Übersetzen. Eine Einführung, Hildesheim. 